\title{
Simplified polymerase chain reaction (PCR)-based sexing assists conservation of an endangered owl, the Norfolk Island Boobook Ninox novaeseelandiae undulata
}

\author{
MICHAEL DOUBLE and PENNY OLSEN
}

\section{Summary}

In 1986 a single Norfolk Island Boobook Owl Ninox novaeseelandiae undulata remained. As part of a re-establishment programme, two male New Zealand Moreporks N. $n$. novaeseelandiae were introduced, one of which survived to pair with the female in the wild and breed successfully. By 1995 the population numbered 12 or 13 individuals of which seven were second generation $\left(\mathrm{F}_{2}\right)$. However, there were only two breeding pairs. As the II hybrids could not be sexed using morphometrics we developed a molecular method based on a recently described avian polymerase chain reaction (PCR)-based sexing technique. The population was found to contain six females and five males. A scarcity of mature males was established as the main factor slowing the recovery effort.

Recent progress in molecular biology has revolutionized several fields, not least conservation biology (e.g. Griffiths and Tiwari 1995, Avise 1994, 1996). Among other advances, relatively simple techniques now allow accurate sexing of individuals, sometimes without the risks associated with handling (Griffiths and Tiwari 1993). Often such knowledge is critical to conservation efforts.

The Norfolk Island Boobook Ninox novaeseelandiae undulata is confined to the small, isolated Norfolk Island Group, an Australian territory. It is one of about 26 of the world's owl taxa listed as endangered and currently the only endangered owl taxon in Australia (Clarke et al. 1978, Garnett 1992). On plumage characteristics, morphological and biogeographical grounds, the owl is classified as a large, distinctive subspecies of the New Zealand Morepork N. $n$. novaeseelandiae (Olsen 1996). Recent molecular analyses confirm that the New Zealand owl is the closest relative (L. Christidis and J. Norman pers. comm., National Museum, Victoria, Australia). In 1986 only one Norfolk Island Owl, a female, was extant (Olsen et al. 1989). As part of a re-establishment programme, two male New Zealand Moreporks were introduced, one of which survived to pair with the female and breed successfully (Olsen 1996). By late 1995, the population numbered 12 or 13 individuals of which seven were second generation $\left(F_{2}\right)$. However, there were only two breeding pairs.

Norfolk Island owls are significantly larger than New Zealand Moreporks. Because both are sexually dimorphic, with females the larger sex, New Zealand females approach Norfolk Island males in size and weight (Olsen et al. 1989, Olsen 1996). This has created difficulties in determining the sex of the hybrid 
offspring using morphometrics. Surgical sexing is an unacceptable risk when numbers are so low.

A lack of knowledge of the sex ratio of the population has hampered management of the owls. Assessment of early progress suggested an apparent shortage of mature males to form breeding pairs (Olsen 1996). Without knowledge of the sex of the younger non-breeding individuals, an informed appraisal of a proposal to introduce more males from New Zealand was difficult.

The recovery effort is carried out in situ with minimal intervention. However, when nestlings are banded, a small blood sample is taken routinely. DNA extracted from these blood samples was used to sex the 11 hybrid offspring. The sexing method was based on techniques described by Griffiths and Tiwari (1995) and Griffiths et al. (1996). Polymerase Chain Reaction (PCR) primers P8 (R. Griffiths and R.J.G. Dawson, unpubl. data) and P2 (Griffiths and Tiwari 1995) amplify two regions, one within the CHD-W gene and another within an homologous gene, CHD-NW (Griffiths et al. 1996). In birds, CHD-W is linked to the female-specific W chromosome whereas CHD-NW is situated within either the $Z$ chromosome or an autosome (Griffiths et al. 1996). Thus DNA samples from females are expected to produce two PCR products whereas samples from males produce one.

PCR reactions were carried out in an FTS-960 Thermal Sequencer (Corbett Research) following a profile of: one cycle of 3 minutes at $94{ }^{\circ} \mathrm{C}, 1$ minute at $57^{\circ} \mathrm{C}$ and 1 minute at $72^{\circ} \mathrm{C}$; followed by 29 cyçles of 30 seconds at $94{ }^{\circ} \mathrm{C}, 30$ seconds at $57^{\circ} \mathrm{C}$ and 30 seconds at $72{ }^{\circ} \mathrm{C}$. Each $25 \mu \mathrm{l}$ PCR reaction included 1.25 units Taq polymerase (Pharmacia), manufacturer's PCR buffer (final concentration: $50 \mathrm{mM} \mathrm{KCl}, 1.5 \mathrm{mM} \mathrm{MgCl}_{2}$, $10 \mathrm{mM}$ Tris- $\mathrm{HCl}$, pH 9.0; Pharmacia), $0.2 \mathrm{mM}$ of each nucleotide (Promega), $0.2 \mu \mathrm{M}$ of each primer and $\sim 120 \mathrm{ng}$ genomic DNA. Initially, products were visualized on a $1 \%$ agarose gel stained with ethidium bromide.

Fragment-specific restriction using DdeI or HaeIII (Griffiths and Tiwari 1995, Griffiths et al. 1996) was successful in only one (Crimson Rosella Platycercus elegans) of the six species we tested. However, in five of the six species (all except the owl) it was possible to resolve the two products amplified from females, without restriction, simply using a $3 \%$ agarose gel. Unfortunately, the products amplified from female Boobook Owls proved to be too similar in size to be resolved in agarose and a 6\% denaturing polyacrylamide gel was required to provide adequate resolution (Figure 1). To visualize the PCR products in acrylamide, forward primers end-labelled with gamma ${ }^{32} \mathrm{P}-\mathrm{dATP}$ (o.8 $\mu \mathrm{Ci} / \mathrm{pmol}$ of primer) were included in each PCR reaction mix. The polyacrylamide gel was run for 1.5 hours at 35 Watts, dried and exposed overnight. This gave a distinctive one- or two-band pattern for each of the 11 owls, indicating that the hybrid population was composed of six females and five males (Figure 1). The validity of the technique was confirmed by its correct assignment of sex to all known-sex individuals tested. These included six owls of known sex (included in Figure 1), based on their breeding histories, and several individuals of the five other species ( $n>10$ for both genders of each species; sexually monomorphic species sexed by dissection; representative individuals shown in Figure 1).

Thus the sex ratio of the owl population was almost unity and the supposed 


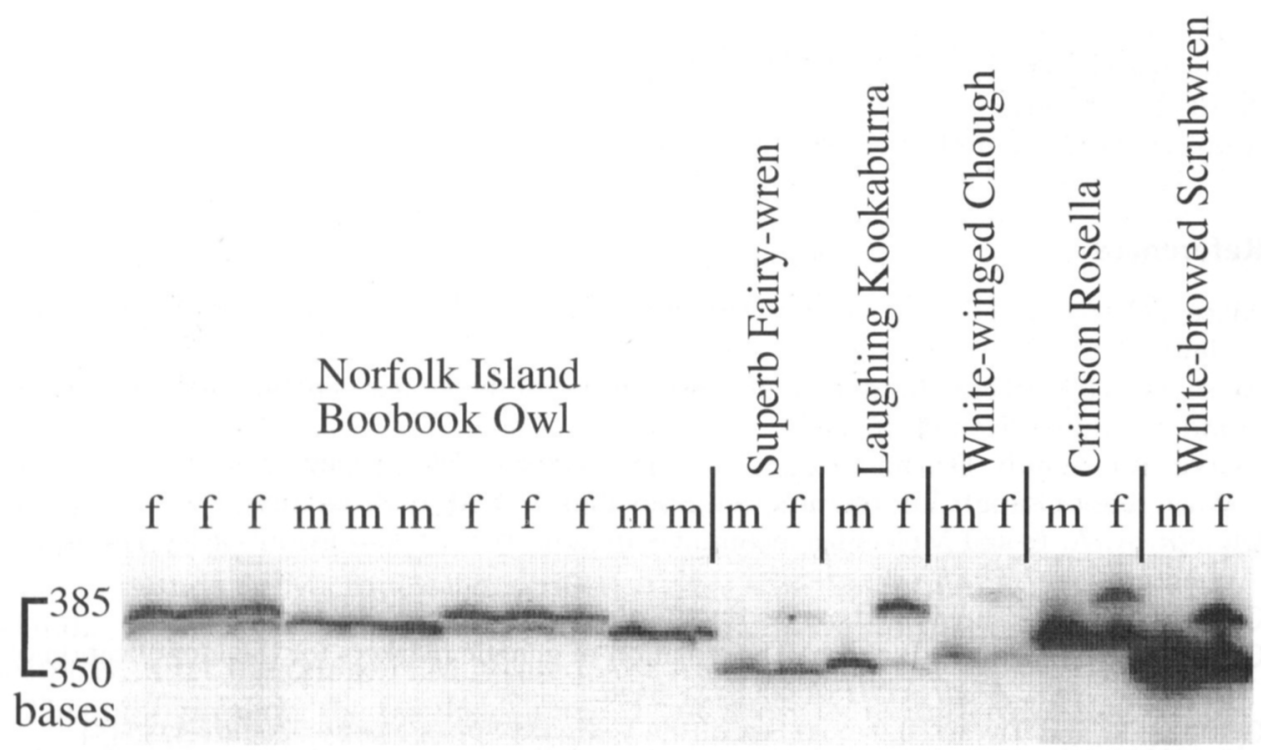

Figure 1 . The distinctive one- ( $\mathrm{m}$, male) or two- ( $\mathrm{f}$, female) band pattern produced by PCRamplification of DNA samples using the P2 and P8 primers. Sex-specific band patterns produced by the eleven individuals comprising the entire hybrid population of the Norfolk Island Boobook Owl in 1995 are shown. Examples of band patterns produced from known-sex individuals of five other species (Superb Fairy Wren Malurus cyaneus, Laughing Kookaburra Dacelo novaeguineae, Crimson Rosella P. elegans, White-winged Chough Corcorax melanorhamphos, White-browed Scrubwren Sericornis frontalis) illustrate the universality of the technique. All products were run on a $6 \%$ denaturing gel and visualized by end-labelling the P8 primer with 32P. Note: with the exception of the the Norfolk Island owl, PCR-products from all species shown can be resolved more simply, in a $3 \%$ agarose gel.

scarcity of mature males was established as the main factor slowing the recovery effort. Limited data suggest that males mature at 3 years. If this is so, there is the potential for another two males to join the existing two mature males in the 1996 breeding population (and two more in 1998). Early results from the 1996 breeding season indicate that at least one of the newly matured males has paired and produced chicks.

This simple PCR-based technique has been applied successfully to six taxonomically distant species and avoids the problem, discussed by Lessells and Mateman (1996), of finding a fragment-specific restriction site. It would have been useful at the commencement of the owl project, when uncertainty over the sex of the last extant individual of this little-known subspecies was a major concern. At this stage of the programme it is providing invaluable information for management.

\section{Acknowledgments}

We are particularly grateful to Richard Griffiths for generously sharing techniques and primers. Various people supplied DNA from individuals of known sex. P.O. is consultant 
to the owl recovery programme, which is supported by Environment Australia (EA). Many people have contributed to the project, particularly Derek Greenwood and Ron Ward (EA), whose fieldwork and advice was invaluable. We thank Stephen Yezerinac, Andrew Cockburn and Rob Heinsohn for their comments on the manuscript.

\section{References}

Avise, J.C. (1994) Molecular markers, natural history and evolution. New York: Chapman and Hall.

Avise, J.C. (1996) Three fundamental contributions of molecular genetics to avian ecology and evolution. Ibis 138: 16-25.

Clarke, R.J., Smith, D.G.and Kelso, H. (1978) Working bibliography of owls of the world. Washington: Raptor Information Centre, National Wildlife Federation.

Dhondt, A. A. (1996) Molecular techniques in conservation and evolutionary biology: a quantum leap? TREE 11: 147-148.

Garnett, S. (1992) Threatened and extinct birds of Australia. RAOU Report 82.

Griffiths, R. and Tiwari, B. (1993) The isolation of genetic markers for the identification of sex. Proc. Natn. Acad. Sci. USA 90: 8324-8326.

Griffiths, R. and Tiwari, B. (1995) Sex of the last wild Spix's Macaw. Nature 375: 454.

Griffiths, R., Daan, S.and Dijkstra, C. (1996) Sex identification in birds using two CHD genes. Proc. Roy. Soc. (Lond.) B263: 1251-1256.

Lessells, K.and Mateman, C. (1996) Molecular sexing of birds. Nature 383: 761-762.

Olsen, P. D. (1996) Re-establishment of an endangered subspecies: the Norfolk Island Boobook Owl Ninox novaeseelandiae undulata. Bird Conserv. Internatn. 6: 63-80.

Olsen, P. D., Mooney, N. J. and Olsen, J. (1989) Status and conservation of the Norfolk Island Boobook Ninox novaeseelandiae undulata. Pp. 415-422 in B.-U. Meyberg and R.D. Chancellor, eds. Raptors in the modern world. London: World Working Group on Birds of Prey.

MICHAEL DOUBLE and PENNY OLSEN

Division of Botany and Zoology, Australian National University, ACT 0200, Australia. 